\title{
The Effect of Political Volatility on Capital Markets in EU Accession and Neighborhood Countries
}

\author{
Christopher A. Hartwell \\ Department of International Management \\ Kozminski University \\ ul. Jagiellonska 57-59, 03-301 Warsaw, POLAND \\ M: +48 538175826 \\ chartwell@kozminski.edu.pl; Christopher.hartwell@case-research.eu
}

\begin{abstract}
:
Political instability has the potential to disrupt financial markets. But how do political institutions affect financial movements in an environment where all institutions are in flux? This paper looks at the effects of formal and informal political volatility in the new EU countries of Central and Eastern Europe, in the Eastern Neighborhood, and farther afield in Central Asia to answer this question. Using asymmetric GARCH modeling on monthly data, I find that informal political volatility has a significant negative effect on stock returns, while formal political institutions generate much higher financial volatility than changes in monetary policy.
\end{abstract}

\section{Keywords:}

Volatility, political institutions, elections, terrorism, EU, stock markets

JEL Classifications: G20, O43, P30

\section{ACKNOWLEDGEMENTS}

The author wishes to thank Sander M. ljmker for his excellent research assistance, Grzegorz Poniatowski for his suggestions, Ali Kutan and participants at the $7^{\text {th }}$ annual Conference on "Economic Challenges in Enlarged Europe" in Tallinn in June 2015 for their comments, and the organizers and attendees of the Portsmouth-Fordham Conference on Banking and Finance in September 2016 (especially Fotios Pasiouras, Mohammad Hasan, and Renatas Kizys) for their insights. I also wish to thank two anonymous referees and the Editor in Chief for their excellent comments. 


\section{Introduction}

The lingering economic effects of the global financial crisis and subsequent sovereign debt crisis in Europe have been compounded by an upswing in political volatility in the European Union (EU), especially in the new members of Central and Eastern Europe (CEE). Referenda, surprise election outcomes, and the fall of governments have been increasing in pace and frequency since 2007 but especially during the height of the crisis, making the political environment in many countries uncertain and increasing political risk (Figure 1). While the most visible effect of this volatility has been slowing large-scale initiatives for European integration, especially related to supranational solutions to the ongoing crisis, at the national level, such political volatility has fed into and reinforced macroeconomic instability. This instability has the potential to threaten economic gains made in transition economies over the previous two decades.

Figure 1 - Average Political Risk in EU Accession and Neighborhood Countries, 2006-2012

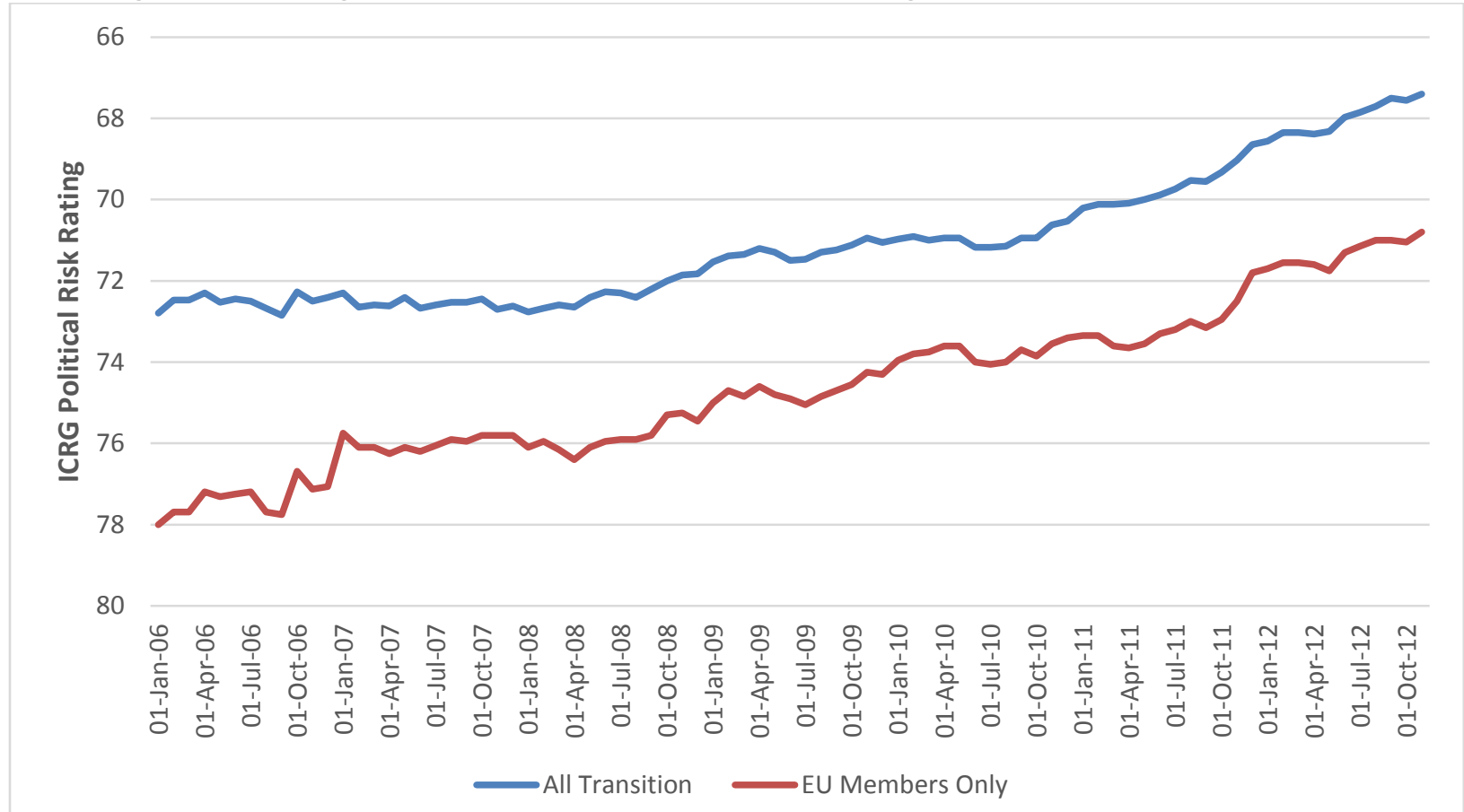

Source: International Country Risk Guide (ICRG) and author's calculations. Lower numbers indicate higher political risk.

This relationship between political instability and sub-optimal economic outcomes has been explored in recent papers such as Fatas and Mihov (2013) and Aisen and Veiga (2013), with empirical evidence showing consistently negative effects of political volatility on economic growth and investment: for example, Heinsz (2004) provides evidence for 172 countries that political volatility leads to policy volatility and dampened growth, while Gurgul and Lach (2013) show that government changes have a negative impact on growth in Central and Eastern Europe. Further extensions to this research have explored the effect of political volatility on other facets of the economy, including financial markets, with a large literature shows the effect of political changes on capital markets, either via the effect of political news on financial sector volatility (led by Engle and Ng [1993]) or the functioning of political institutions themselves. For example, Arin et al. (2013) traced the relevance of political variables for 
financial volatility in OECD countries while Hartwell (2014a) examined the effect of democratic transitions on stock markets.

The literature relating political instability to financial market outcomes has identified two interlinked but distinct channels through which political volatility can impact capital markets: first, via the direct exercise of monetary policy and how it is utilized; and second, via a more indirect channel of overall policy uncertainty that accompanies both regularly-scheduled elections and informal political instability. The first channel has been extensively studied, with a long and established literature linking monetary policy with both levels of asset returns (Thorbecke 1997) and volatility of returns (Bernanke and Gertler 2012). The second channel has also seen some interesting work done, mainly relating the impact of government changes and political news on stock market volatility (Beaulieu et al. 2005).

However, what happens when the whole institutional make-up of an economy is in flux? How do financial markets deal with an environment of uncertain monetary policy and political institutional volatility? This is precisely the situation that the transition economies of Central and Eastern Europe and the former Soviet Union (FSU) have faced over the past 25 years, as they have been building modern capital markets at the same time they have been erecting market-supporting institutions (Beck and Levine 2008) or importing European institutions wholesale. In many ways, the imperative of creating new institutions to facilitate the market economy collided with the challenge of fostering capital markets to finance the transition; in particular, the necessary change of political institutions engendered the exact sort of instability that would negatively impact financial markets. Moreover, the result of the political changes in the CEE and FSU countries was not readily apparent, meaning that markets would be even more susceptible to volatility from politics. Would the latest change in party mean a return to a quasi-socialist past or had necessary institutional reforms been "locked-in?"

The purpose of this paper is thus to explore these links between political volatility and capital market volatility in transition, including new EU members, pre-accession countries, and countries in the Eastern Neighborhood, controlling for policy changes and the effect of EU membership. The main hypothesis is that increased political institutional volatility will feed through directly to stock market volatility, independent of and regardless of what is occurring in the monetary policy channel. Indeed, in an environment of rapid institutional change, monetary policy should mean less for the stock market's prospects than political institutional vacillations. While capturing the direct effects of political volatility may be difficult, through utilization of appropriate metrics we may be able to discern the channels in which volatility operates.

This paper makes a unique contribution to the literature in two ways. First, this analysis builds on recent empirical work (Goodell and Vähämaa 2013, Hartwell 2014a) to examine the effects of political volatility on the financial markets of transition economies, but extending it to include the effects of integration with Europe. The EU itself may provide a buffer, with the prospect of EU accession somehow insulating countries against too-volatile swings. Secondly, this paper also has assembled, for the first time, a comprehensive dataset on monthly political changes across transition economies. While Hartwell (2014a, 2014b) examined the effects of volatility surrounding democratic transitions, this paper goes further in examining the broad spectrum of political volatility, both formal and informal.

\section{Literature Review}

As noted above, there are two main channels through which political instability can affect stock market movements: the first is directly via monetary policies, which may change due to political ideology or 
policy preferences. There is a large and established literature on the effects of monetary policy on stock market movements (Thorbecke 1997, Rigobon and Sack 2003), with Hsing and Hsieh (2012) showing that the growth of M2/GDP directly contributed to stock market volatility in Poland. Extending this literature to the drivers of the monetary policy volatility, we can see that there are proven links between the volatility of inflation and political volatility (Aisen and Vega 2008), with Cukierman et al. (1992) finding that fragile polities tend to rely more on seignorage as a way to overcome political obstacles for expansionary fiscal policies. Moreover, political instability has been shown to be both a cause and an effect of monetary profligacy, due to the endogeneity of monetary policy institutions; as Carmignani et al. (2008) demonstrate, political instability can hamper central bank functioning (in particular its independence), and thus lead directly to higher inflationary outcomes. This link was further extended by Papadamou et al. (2014) to show that central bank independence affects stock market volatility, thus closing the circle of causality from political instability to monetary institutions to financial volatility.

The second, and perhaps more independent, channel in which political instability can influence the stock market is related to the uncertainty regarding broader economic policies that political volatility can engender. An enormous amount of scholarship has been dedicated to understanding the effect of "news" on financial markets (see Hayo and Kutan 2005); the underlying premise of these analyses is that policy uncertainty up until and after the moment of a political or economic announcement drives higher levels of volatility than in periods of no news. In the case of political institutions, however, the "news" that can occur is not just limited to one press release, but is related to a multi-year policy stance (in the case of elections) or the repercussions of informal and possibly recurring political instability (as in a terrorist attack) for the broader economy. These effects of policy uncertainty on financial markets, driven by underlying political volatility, can be magnified in countries where there is less experience with capital markets (Białkowski et al. 2008). In any case, as Low et al. (2011) show, political stability more broadly defined is an unmitigated positive for stock markets, as it removes investor concerns about policy uncertainty and lowers risk premia. On balance, markets do not like to be surprised, whether in the context of a single news briefing or in drastic changes in political institutions.

While there is a broad theoretical basis relating political volatility to stock market volatility, in order to understand which specific political institutions may have a greater impact on financial markets we need to refer to the growth literature, where much more research has been done in examining the effect of separate political institutions on growth volatility. For example, Brunetti and Weder (1998) found that constitutional changes (their measure of volatility) negatively correlated with growth, while Svensson (1998) found that the probability of an imminent political change harmed property rights formation, which then in turn hampered investment. Berggren et al. (2011) find that instability in legal and policy institutions in rich countries actually contributes significantly to higher growth rates, while instability of social institutions is a drag on growth across all countries. However, Yang (2011) also finds that normal democratic processes tend to increase macroeconomic instability across the board, a finding echoed by Boutchkova et al. (2012), who conclude that the variance of a country's major index return doubles during an election week.

In contrast to the growth literature, there is comparatively less work done on specific political institutions and stock market volatility, with a focus almost exclusively on elections as the drivers of equity variance. Recent work from Białkowski et al. (2008) and Goodell and Vähämaa (2013), show the role of political uncertainty as encapsulated in elections tend to drive volatility around the event date. As Goodell and Vähämaa (2013:1116) note, the political uncertainty of an election "presumes that information regarding the probability of a particular election winner reflects information about future macroeconomic policy." Thus, approaching elections engender market anxiety, leading to a revision and 
continuous updating of expectations regarding future macroeconomic changes. Given the varying timehorizons inherent in a capital market and the differing behaviors of its participants, this can thus lead to volatility within a stock market as allocations are changed and positions reversed.

However, much like in the growth literature, there are differential effects of different types of political volatility. In particular, formal political changes such as an election may be anticipated well in advance, as well as being a one-off affair (unless there is scope for a run-off), so that volatility may settle quickly after an election (Santa-Clara and Valkanov 2003); moreover, the behavior of the party in power may be established fairly early on, or coalition talks concluded quickly, also contributing to a return to normalcy. Thus, these formal political channels may be supplemented by informal political volatility, including a host of variables. For example, external conflict or war in one's neighborhood can have a direct impact on stock market returns, as shown in the Middle Eastern context by Fernandez (2007) regarding the Iraq War. Terrorism as well may have severe impacts on financial volatility (Essaddam and Karagianis 2014), as may other manifestations of internal conflict. Even political instability as milquetoast as an unexpected election result (Castells and Trillas 2013) or a senator switching parties (and thus control of government, see Jayachandran [2006]) can have major impact on financial market volatility in excess of normal.

Finally, as noted in the introduction, the case of transition economies, where the entire institutional system is in a state of flux, may exhibit greater pass-through to financial volatility from political volatility than the oft-studied OECD countries. While Hartwell (2014a) found little relationship between democratic volatility (i.e. changes in the ability of individuals to influence the political process) and financial volatility, other types of informal instability may exert a stronger influence on burgeoning capital markets. Indeed, in places such as Russia where private organized crime once ruled but has now been overtaken by a predatory state (Gans-Morse 2012), the (legal) ability to enter the political system have little practical effect if your life is in danger. Thus, it may appear that informal political institutions, and their (in)stability, would have more of an impact than formal channels.

\section{Model and Empirical Strategy}

With the experience of concurrent EU accession and economic transition relatively unexplored from the standpoint of political institutional volatility, the purpose of this paper is to examine three main hypotheses:

H1: Increased political institutional volatility in transition economies fed through directly to stock market volatility

Building on the extensive literature noted above, we should expect to see similar (if not more pronounced) effects in transition economies on financial markets from all types of political changes. In developed economies, strong institutions act as a buffer for bad news and political turmoil; no matter how bad things get in the political arena, the presence of strong institutions means a line beyond which policies cannot progress. And, given the semi-permanent nature of institutions, further moves that could shatter market confidence would require changing these institutions, a slower and longer-term process. However, Institutions in transition are inherently fragile, with nascent monetary institutions, incomplete macroeconomic stabilization, and property rights and other economic institutions just starting to be built. This reality means that the line in the sand has not yet been drawn. Political 
instability in transition could just as easily wreck the system as save it, and thus I anticipate that political volatility in transition should translate into persistently volatile capital markets.

H2: Informal political volatility should have a greater impact on stock markets in transition economies than formal political volatility.

Formal political volatility such as elections should have a longer-lasting effect on stock markets in mature economies due to shifts in policy. In particular, worries about a change of party may show up in stock markets as a rational response to political change. Shifts in political winds may signal differential treatment of dividends, taxation, or other areas which may impact upon capital markets, thus making financial volatility a rational response. However, in transition economies, the relatively youthful nature of all institutions, as well as the reality that political institutions in some countries are Potemkin in nature (as in Belarus), may make formal volatility matter less for stock market performance. Similarly, the relatively regular nature of elections would also have less of an impact on firm and capital-market dynamics.

Hypothesis 2 is derived from this reality, based on the assumption that informal political volatility would eventually manifest itself in formal political volatility. However, while responses to formal political volatility may be rational, a response to perceived changes in macroeconomic policy, informal political may be irrational, given that terrorism or external conflict have no such clear-cut link to capital market performance. But, as the manifestation of informal political volatility may both create short-term disruptions and longer-term uncertainty about future political changes, especially in an atmosphere of institutional fragility, we would expect to see informal volatility be the dominant factor in financial volatility in transition.

H3: Increased political institutional volatility in transition economies fed through to stock market volatility, independent of the monetary policy channel

Finally, while both formal and informal political volatility can have a direct influence on monetary policy (for example, Aisen and Veiga (2008) show political instability is associated with inflation volatility), it is plausible that political volatility in transition will also have a direct consequence on stock market volatility through expectations and policy effects (the rational response noted above). This effect should also be more pronounced in transition economies, given the relative fragility of their political institutions and capital markets vis a vis more advanced economies (Forestiere 2010), supplemented by the fact that the entire transition itself was a process of expectations augmentation.

In order to test these hypotheses, a basic model, without controls, relating financial volatility to institutional changes will be structured as follows:

$$
\text { (1) } y_{i t}=\alpha+\beta \text { POLINSTITUTIONS } i t-1+\gamma M O N E T A R Y_{i t-1}+\varepsilon_{i t}
$$

Where $y_{i t}$ is the change in the overall stock market index for each country, as measured by the (absolute value of the change in the) log of returns (as suggested by Nikkinen et al. 2008):

$$
\text { (2) } y_{i t}=\left(\sum_{t=1}^{N}\left[\log \left(p_{i t}\right)-\log \left(p_{i t_{-1}}\right)\right] * 100\right)
$$

Where $p$ is the index at time $t$ for country $i$ less the price of the index at time $t-1$. The daily data is then summed over the month and averaged to give a mean return for that month. 
The change in returns, and eventually financial market volatility, is determined in Equation 1, as noted above, by two major factors, monetary policy and political institutions, included as vectors here. To measure monetary policy, two metrics are utilized. The simplest is the period change in $\mathrm{M} 2$ (percent), to proxy for expansionary/contractionary monetary policy. Given the time that it may take for money changes to pass-through to price indices, using the magnitude and direction of the money supply makes sense as an immediate barometer of monetary policy, with the added benefit of complete data series for the countries included here. But this measure may miss the overall climate in which monetary policy occurs, and in particular if monetary policy is subjected to larger gyrations than over one period; such monetary policy volatility may have a much larger effect on financial volatility (as shown in Okoli 2012) due to difficulty in expectations formation. In order to capture the possibility of monetary policy volatility being the culprit for financial volatility, I utilize the rolling 3-month standard deviation of changes in M2. To alleviate simultaneity concerns, all independent variables are lagged one period.

The political institutions variable shown in Equation 1 are various proxies for political instability, including both clear-cut signs of "informal" political instability (acts of terrorism, internal conflict) as well as more common "formal" instability (change of parliamentary government or formal elections). The full description of the political variables is shown in the Appendix.

To capture the volatility aspect of financial markets in relation to political institutions, I utilize a GARCH specification to generate the volatility metrics (Table 1 shows that conditional heteroskedasticity is pervasive in our data, as encapsulated in the significant Box-Ljung Q-statistics and the Q-squared statistics). Moreover, given that we can anticipate asymmetric responses to political volatility, where negative political volatility has more pronounced and persistent effect on stock market volatility than positive political shocks, a variety of asymmetric GARCH specifications may be utilized; based on diagnostics, a GJR-GARCH $(2,2)$ model of Glosten et al. (1993) outperforms other specifications such as (the admittedly more flexible) EGARCH by all conventional information criteria. ${ }^{1}$ In addition, where appropriate either student's T or a generalized error distribution (GED) is used to capture the "fat tails" of the political institutional variables.

Finally, the panel nature of our data recommends using a panel-GARCH framework rather than countryby-country for a simple reason: given that transition was occurring simultaneously across a number of countries from the same region, panel GARCH helps us to capture cross-sectional dependence. As Lee (2010:143), correctly notes, panel-GARCH models "entail potential efficiency gains in estimating the conditional variance and covariance processes by incorporating relevant information about heterogeneity across economies as well as their interdependence."

The GJR-GARCH framework starts with a base model of:

$$
\text { (3) } y_{t}=\mu+\varepsilon_{t}
$$

\footnotetext{
${ }^{1}$ A further benefit to the GJR-GARCH model is how EGARCH models the conditional variance. EGARCH places extra weight on more recent observations, making each shock that enters the system additive. However, in the case of institutional changes, which may amplify over time, the volatility shock is more likely to be multiplicative, a feature that the GJR-GARCH model captures (Duan 1997).
} 
Where $\mu$ is the mean equation shown above as equation 1 . The innovation in the GJR-GARCH model concerns the $\varepsilon_{t}$ term, which contains the seeds of the asymmetric variance equation (and thus the modelling of financial volatility):

and

$$
\text { (4) } \varepsilon_{t}=\sigma_{t} z_{t}
$$

$$
\text { (5) } \sigma_{t}^{2}=\kappa+\sum_{i=1}^{p} \gamma_{i} \sigma_{t-i}^{2}+\sum_{j=1}^{Q} \alpha_{j} \varepsilon_{t-j}^{2}+\sum_{j=1}^{Q} \xi_{j} I\left[\varepsilon_{t_{-j}}<0\right] \varepsilon_{t-j}^{2}
$$

Equation 5 represents the volatility of the returns variable, with the leverage coefficient in the GJRGARCH model is represented by I; as can be seen, the leverage coefficient is weighted towards negative shocks to capture the persistence of negative changes as distinctly asymmetric from positive shocks. Thus, $l$ is equal to 1 if $\varepsilon_{t-j}$ is less than 0 , and 0 otherwise. Moreover, in order to ensure stationarity, the GJR-GARCH model also imposes four constraints on equation 5 :

(6) $\kappa>0$

(7) $\gamma_{i} \geq 0, \alpha_{j} \geq 0$

(8) $\alpha_{j}+\xi_{j} \geq 0$

(9) $\sum_{i=1}^{p} \gamma_{i}+\sum_{j=1}^{Q} \alpha_{j}+\frac{1}{2} \sum_{j=1}^{Q} \xi_{j} I<1$

For the dataset utilized here, given the auto-correlative nature of the data and based on a partial autocorrelation function (PACF) plot (not shown), an $\operatorname{AR}(n)$ term is also included, with $n=4{ }^{2}$

[Table 1 here]

The dataset assembled for this exercise comes from a large variety of sources and covers 20 transition economies, both EU-accession and non-EU accession, monthly from 1989 to $2012 .{ }^{3}$ This frequency was chosen to deal with the reality of political institutional changes and capital markets: institutions are generally thought of semi-permanent creatures (Hartwell 2013), but in transition, institutional changes move at a higher speed, especially during the process of EU accession (as can be seen in the example of internal conflict, shown across countries in Figure 2). Thus, annual-level data misses the specific causeand-effect of institutional volatility. On the other hand, the structure of financial market data is predicated on high-frequency movements, and utilizing annual averages would not capture the true effects of political changes on capital markets. Instead, I split the difference between broader institutional changes (difficult to track on a daily basis) and stock market changes by examining monthly data.

[Figure 2 here]

\footnotetext{
${ }^{2}$ GARCH was chosen over system-GMM as the high-frequency nature of the data, serial correlation, and its sheer size made GMM inappropriate.

${ }^{3}$ The countries included in the dataset are Belarus, Bosnia, Bulgaria, Croatia, the Czech Republic, Estonia, Hungary, Kazakhstan, the Kyrgyz Republic, Latvia, Lithuania, Macedonia, Mongolia, Poland, Romania, Russia, Serbia, Slovakia, Slovenia, and Ukraine.
} 
Stock market returns were compiled for each country from Bloomberg and CEIC, while M2 and other macroeconomic variables from the IMF's International Financial Statistics (IFS) database (or, where not available, from Eurostat or from the central banks of each economy). The informal political volatility variables were assembled from various sources, including the International Country Risk Guide (ICRG) indicators for political stability. Other formal political indicators were manually coded based on information obtained via public sources such as newspapers, government and Ministry websites, and the Regan and Clark (2013) dataset.

\section{Results and Analysis}

The results of the test of all hypotheses using the simple baseline model of Equation 1 are shown in Table 2, with financial volatility expressed as a function of political volatility. ${ }^{4}$ Table 2 shows the test of Hypotheses 1 and 2 relating political volatility to financial volatility in the absence of controls: across all combinations of political variables, formal political institutional volatility, as proxied by either elections or prime ministerial/cabinet changes, had little effect on stock market returns but, in the case of elections, a strong demonstrable effect on financial volatility. Informal political volatility, on the other hand, had a much larger effect on stock market returns but only a marginally significant effect on volatility, with terrorism having the largest impact. In all specifications, monetary policy consistently both depresses stock market returns slightly while increasing financial volatility. Thus, both Hypothesis 1 and 3 are confirmed, as formal political volatility did feed through to financial volatility, occurring independently of the monetary policy channel. Hypothesis 2, by contrast, is partially confirmed in this simple model, as informal volatility had a larger impact on stock returns than formal political institutions but a much smaller and less significant effect on financial volatility.

[Table 2 here]

The explanation for these results may be found in the nature of the transition process itself. As noted above, transition entailed a change of several institutions simultaneously, with the change in political institutions meaning a power vacuum had also opened up. Given that political shifts could also determine the future of economic transition, and by extension financial markets, elections therefore were of much greater consequence in transition than in developed economies (especially since candidates who campaigned as communists were likely to govern as communists, see Hartwell 2013). While conflict could depress the market for a longer period, the run-up to elections, and the wait-andsee period afterwards while new policies were announced, had far greater potential to rattle financial markets. Additionally, while formal political changes may have been foreseen, they also may have been accompanied by informal political volatility, such as violence against opposition leaders, riots, arrests, or even terrorism. Thus, an election may have expressed both formal and informal political volatility.

However, given that these results are obtained using only institutional and monetary variables, there is a need to include controls which also could plausibly explain financial movements. Unfortunately, a full panoply of macroeconomic or market controls is not available monthly for many transition economies, a problem which leads us to a rather parsimonious control set. Specifically, three additional controls are included to proxy for economic environment. In the first instance, I include GDP growth as an indicator to capture the general economic direction of a country; as in Hartwell (2014a), this statistic is based on

\footnotetext{
${ }^{4} \mathrm{ARCH}, \mathrm{GARCH}$, and AR terms are all significant at the $1 \%$ level, but are not shown in the interest of space. The leverage effect of the GJR-GARCH model also shows that it is a more "correct" model of political volatility.
} 
interpolated quarterly data and thus is a broader indicator of economic direction rather than necessarily capturing the exact state of an economy. ${ }^{5}$ Secondly, it is quite possible that internal financial volatility is occurring mostly independent of politics, and so to capture external financial volatility, I use both the 6month volatility (calculated as a rolling standard deviation) of gold prices and the month-to-month volatility of the S\&P500 Index as a control. Finally, as noted above, perhaps monetary policy volatility drives financial volatility, and so rolling standard-deviations of monetary policy are also included.

[Table 3 here]

The results of this specification are shown in Table 3. Each political volatility metric, both informal and formal, is paired with each other as well as with the two monetary policy volatility indicators and the two external volatility variables, resulting in a total of 12 models. Within each triumvirate of formal and informal political instability metrics, certain models appear to be a better fit for the data based on minimization of the AIC, with in particular models 1, 4, 9, and 10 appearing the be the more "correct" ones for understanding the relationship between financial volatility and political volatility. ${ }^{6}$ In these models (and indeed across other, less-well-fit ones), while cabinet and Prime Ministerial changes continue to be an insignificant driver of either stock returns or volatility (significant only when paired with monetary policy volatility), the presence of elections persistently results in higher levels of financial volatility. Similarly, internal tension and terrorism reduce stock returns in the aggregate, but have only a marginally significant effect (dependent upon the specification) on financial volatility.

The picture painted by these results is a simple one, mainly that informal instability can harm overall returns in the short- and even the medium-term, but their effect is often priced in. Conversely, elections may be seen as a one-off event, thus having little effect on stock market returns, but the presence of an election and the policy uncertainty it brings may rattle financial markets. This is especially true in an environment such as a transition economy, where elections, even more so than elsewhere, have consequences. Thus, in terms of our hypotheses above, Hypotheses 1 and 3 regarding the effects of political volatility are confirmed, while Hypothesis 2 has been disproved, as informal volatility has little effect on financial volatility.

\section{The EU Factor}

Given the dispersion of countries in this dataset, perhaps stratifying the data into sub-samples would give more evidence on the impact of political volatility on financial markets. To this end, I include several ways in which to divide the dataset: in the first instance, I include a simple EU accession dummy, coded to 1 for all months for countries that eventually would become a member of the EU (even before their membership) and 0 for those that did not. This dummy captures several integration effects, including the multi-year nature of the EU accession process, which required phased-in institutional adjustments, as well as expectations in both political and financial markets on the permanence of such reforms. Integration with the EU would thus be expected to signal the import of financial stability for the longrun, even if the short-run was still turbulent.

\footnotetext{
${ }^{5}$ A helpful reviewer noted that there might be multicollinearity from GDP growth, as $M 2$ is already included in the base model. However, given that we are using growth metrics (growth of GDP versus growth of M2) or volatility metrics (growth of GDP versus volatility of $M 2$ growth), this is less of a theoretical problem. Econometrically, there is only a slight positive correlation between the two growth variables $(0.22)$ over the full dataset, and even less correlation between GDP growth and the volatility of M2 growth (-0.16).

${ }^{6}$ In most cases, these models also have the best log likelihood results as well.
} 
However, this simple EU dummy says little about how actual EU membership affected political and financial volatility. To that end, I also include a dummy coded as 1 for each month that a country was actually in the EU, starting with its formal accession date. We would expect to see this dummy have a larger effect on returns and perhaps on financial volatility, as expectations about a country's performance would have actually passed into reality.

[Table 4 here]

Building off the key models noted, Table 4 shows the results of including both of these EU dummies. Somewhat paradoxically, across the board, the dummy for actual EU membership correlates heavily with lower returns in the conditional mean, while overall EU accession status has little effect on returns. More importantly for our examination, countries which eventually attained EU accession appear to have either lowered (model 1, column 1) or wiped out entirely the effect of informal political volatility on returns (models 9 and 10). However, the inclusion of either EU dummy does not change the overall picture of volatility relationships, as elections continue to be a strong predictor of financial volatility even in EU countries; additionally, in model 9 (columns 5 and 6), the inclusion of EU dummies also makes the formal change of Prime Minister/cabinet a predictor of additional volatility. In all specifications, as above, informal volatility is a poor predictor of financial volatility, once again disproving Hypothesis $2 .^{7}$

As a last robustness test, this paper has touched upon deeper issues of institutional volatility, but advances in economic policy uncertainty (typified by Baker, Bloom, and Davis 2016, hereafter BBD) make it possible for us to test if it is in fact institutional or policy uncertainty which is driving capital market volatility. Unfortunately, there are no direct suitable economic policy uncertainty indexes for the countries we examine here, so we are forced to rely on the "European" measure of BBD as a suitable proxy for continent-wide uncertainty (specifically, we utilize the change in the uncertainty index over the month). While not a perfect indicator for measuring country-specific policy uncertainty, this European variable does have the advantage of acting as a stand-in for specific country indexes for the countries who have acceded to the EU; i.e. a large portion of Polish economic policy uncertainty could be captured by the European index from 2004 onward. ${ }^{8}$ For other countries, further afield, the European index could capture global uncertainty or, more importantly, the uncertainty emanating from their largest trading partners.

[Table 5 here]

The results of this exercise are shown in Table 5. Across all specifications, the earlier results hold, with formal political instability having no effect on returns but informal institutional volatility have significant (and in many cases, stronger) negative effects. In regard to volatility, elections continue to be the largest generator of capital market volatility, while internal conflict and terrorism have an impact on financial volatility when paired with prime ministerial or cabinet changes; while the effects are marginally smaller economically, they are much stronger statistically. Finally, to ensure that certain EU members are not biasing these results, I also include the narrower Germany policy uncertainty index, on the reality that emerging Europe's relations were much stronger with Germany than with other members of the "old"

\footnotetext{
${ }^{7}$ Additional robustness tests on the type of party in power are shown in the Appendix.

${ }^{8}$ Unfortunately, it is not possible to disentangle how much of Poland's policy uncertainty is captured by the Europe variable and what remains at a home-grown level.
} 
EU such as Spain or France. These results, shown in the odd-numbered columns of Table 7, do not change our core findings and, indeed, German uncertainty has far less of an effect on capital markets in transition than European uncertainty in general.

\section{Conclusions}

This paper has examined the effects of political volatility and monetary policy on financial volatility in the transition economies of Central and Eastern Europe and countries in the extended European neighborhood. Perhaps not surprisingly, monetary policy remains a major driver of financial volatility, albeit the effect is economically small. More importantly, the results above show that informal political institutions and their volatility were important as a determinants of financial market performance, with informal volatility contributing to far more depressed stock returns than in an environment of no volatility. On the other hand, formal political changes such as elections corresponded with much higher financial market volatility, even as they had no discernible effect on stock market returns. In this sense, our conjecture that transition markets would behave differently from more-established ones was erroneous, as the effect of elections was much more pronounced than other manifestations of political volatility. Interestingly, EU membership appears to have lowered returns on average but acted as an anchor of stability to prevent informal volatility translating into financial volatility, suggesting that other institutional mechanisms are at play.

Future work is called for to deal explicitly with the direct and indirect influence of political institutions on monetary institutions, and if either of these types of volatility influences the functioning of monetary policy in general. Such an examination would be crucial not only for new Member States of the EU or their neighbors further east, but would also be of interest within the Eurozone. Additionally, it would be helpful to understand better how informal political institutions interact with formal ones in transition: when does "informal" volatility suddenly become "formal?" As a corollary to this, there also may be other, better proxies for informal political volatility than the ones utilized here, which can better capture where this dividing line is. Econometrically, there may also be scope to utilize GARCH-MIDAS modelling in order to expand the control set of this paper (Alper et al. 2012), incorporating lower frequency variables as explanators for higher-frequency changes; such an approach may also capture more volatility dynamics at the daily level which may have been vitiated by monthly aggregation. All of these issues may occupy researchers for years, and this paper has only begun to point the way to new and exciting avenues of research in relating political institutions to capital markets.

\section{REFERENCES}

Aisen, A., and Veiga, F. J. (2008). "Political instability and inflation volatility," Public Choice, Vol. 135 nos. 3-4, pp. 207-223.

(2013). "How does political instability affect economic growth?" European Journal of Political Economy, Vol. 29 No. 1, pp. 151-167.

Alper, C. E., Fendoglu, S., \& Saltoglu, B. (2012). MIDAS volatility forecast performance under market stress: Evidence from emerging stock markets. Economics Letters, 117(2), 528-532. 
Arin, K. P., Molchanov, A., and Reich, O. F. (2013). "Politics, stock markets, and model uncertainty," Empirical Economics, Vol. 45 no. 1, pp. 23-38.

Baker, S. R., Bloom, N., \& Davis, S. J. (2016). Measuring economic policy uncertainty. The Quarterly Journal of Economics, Vol. 131 no. 4, pp. 1593-1636.

Beaulieu, M. C., Cosset, J. C., and Essaddam, N. (2005). "The impact of political risk on the volatility of stock returns: The case of Canada," Journal of International Business Studies, Vol. 36 no. 6, pp. 701-718.

Bernanke, B., \& Gertler, M. (2012). "Monetary Policy and Asset Price Volatility," in Evanoff D.D., Kaufman G.G., and Malliaris, A.G. (eds.), New Perspectives on Asset Price Bubbles, Oxford, New York, pp. 173-210.

Białkowski, J., Gottschalk, K., and Wisniewski, T. P. (2008). "Stock market volatility around national elections," Journal of Banking \& Finance, Vol. 32 no. 9, pp. 1941-1953.

Boutchkova, M., Doshi, H., Durnev, A., and Molchanov, A. (2012). "Precarious politics and return volatility," Review of Financial Studies, Vol. 25 no. 4, pp. 1111-1154.

Brunetti, A., and Weder, B. (1998). "Investment and institutional uncertainty: a comparative study of different uncertainty measures," Weltwirtschaftliches Archiv, Vol. 134 no. 3, pp. 513-533.

Castells, P., and Trillas, F. (2013). "The effects of surprise political events on quoted firms: the March 2004 election in Spain," SERIEs, Vol. 4 no. 1, pp. 83-112.

Carmignani, F., Colombo, E., and Tirelli, P. (2008). "Economic and socio-political determinants of de facto monetary institutions and inflationary outcomes," the BE Journal of Macroeconomics, Vol. 8 no. 1.

Cukierman, A., Edwards, E., and Tabellini, G. (1992). "Seignorage and Political Instability," American Economic Review, Vol. 82 no. 3, pp. 537-555.

Duan, J.-C. (1997). Augmented GARCH (p, q) process and its diffusion limit. Journal of Econometrics, Vol. 79 no.1, pp. 97-127.

Engle, R. F., and Ng, V. K. (1993). "Measuring and testing the impact of news on volatility," Journal of finance, Vol. 48 no. 5, pp. 1749-1778.

Essaddam, N., and Karagianis, J. M. (2014). "Terrorism, country attributes, and the volatility of stock returns," Research in International Business and Finance, Vol. 31 no. 1, pp. 87-100.

Fatás, A., and Mihov, I. (2013). "Policy volatility, institutions, and economic growth," Review of Economics and Statistics, Vol. 95 no. 2, pp. 362-376.

Fernandez, V. (2007). "Stock market turmoil: worldwide effects of Middle East conflicts," Emerging Markets Finance and Trade, Vol. 43 no. 3, pp. 58-102.

Forestiere, C. (2010). "Political Volatility and Governance in East Central Europe," Slavic Review, Vol. 60 no. 4 , pp. 903-924. 
Gans-Morse, J. (2012). "Threats to property rights in Russia: from private coercion to state aggression," Post-Soviet Affairs, Vol. 28 no. 3, pp. 263-295.

Glosten, L. R., Jagannathan, R., and Runkle, D. E. (1993). “On the relation between the expected value and the volatility of the nominal excess return on stocks," Journal of Finance, Vol. 45 no. 5, pp. 17791801.

Goodell, J.W., and Vähämaa, S. (2013). "US presidential elections and implied volatility: The role of political uncertainty," Journal of Banking \& Finance, Vol. 37, no. 3, pp. 1108-1117.

Gurgul, H., and Lach, Ł. (2013). "Political instability and economic growth: Evidence from two decades of transition in CEE," Communist and Post-Communist Studies, Vol. 46 No. 2, pp. 189-202.

Hartwell, C.A. (2013). Institutional Barriers in the Transition to Market: Explaining Performance and Divergence in Transition Economies. Basingstoke: Palgrave Macmillan.

(2014a). The impact of institutional volatility on financial volatility in transition economies: a GARCH family approach. Bank of Finland Institute for Economies in Transition (BOFIT) Working Paper No. 6/2014.

(2014b). "Do (Successful) Stock Exchanges Support or Hinder Institutions in Transition Economies?" Cogent Economics \& Finance, Vol. 2 no. 2.

Hayo, B., and Kutan, A.M. (2005). "IMF-Related News and Emerging Financial Markets," Journal of International Money and Finance, Vol. 24 no. 7, pp. 1126-1142.

Henisz, W. J. (2004). "Political institutions and policy volatility," Economics \& Politics, Vol. 16 no. 1, pp. 127.

Hsing, Y. and Hsieh, W-J. (2012). "Impacts of Macroeconomic Variables on the Stock Market Index in Poland: New Evidence," Journal of Business Economics and Management, Vol. 13 no. 2, pp. 334-343.

Jayachandran, S. (2006). "The Jeffords Effect," Journal of Law and Economics, Vol. 49 no. 2, pp.397-425.

Lee, J. (2010). The link between output growth and volatility: Evidence from a GARCH model with panel data. Economics Letters, Vol. 106 no. 2, pp. 143-145.

Low, S. W., Kew, S. R., and Tee, L. T. (2011). "International evidence on the link between quality of governance and stock market performance," Global Economic Review, Vol. 40 no. 3, pp. 361-384.

Merton, R. (1980). "On estimating the expected return on the market: An explanatory investigation," Journal of Financial Economics, Vol. 8 no. 4, pp. 323-361.

Nikkinen, J., Omran, M. M., Sahlström, P., and Äijö, J. (2008). Stock returns and volatility following the September 11 attacks: Evidence from 53 equity markets. International Review of Financial Analysis, 17(1), pp. 27-46. 
Okoli, M.N. (2012). "Return-volatility interactions in the Nigerian stock market," Asian Economic and Financial Review, Vol 2 no. 2, pp. 389-399.

Papadamou, S., Sidiropoulos, M., and Spyromitros, E. (2014). "Does central bank transparency affect stock market volatility?" Journal of International Financial Markets, Institutions and Money, Vol. 31, pp. 362-377.

Perry, P. (1982). The time-variance relationship of security returns: Implications for the returngenerating stochastic process. Journal of Finance, Vol. 37 no. 3, pp. 857-870.

Regan, P, and Clark, D. (2013). Institutions and Elections Project Codebook. SUNY Binghamton, available at: http://www.binghamton.edu/political-science/institutions-and-elections-project.html.

Rigobon, R., and Sack, B. (2003). "Measuring The Reaction of Monetary Policy to the Stock Market," Quarterly Journal of Economics, Vol. 188 no. 2, pp. 639-669.

Santa-Clara, P., and Valkanov, R. (2003). "The presidential puzzle: Political cycles and the stock market." The Journal of Finance, Vol. 58 no. 5, pp. 1841-1872.

Svensson, J. (1998). "Investment, property rights and political instability: Theory and evidence," European Economic Review, Vol. 42 no. 7, pp. 1317-1341.

Thorbecke, W. (1997). "On stock market returns and monetary policy," Journal of Finance, Vol. 52 no. 2, pp. 635-654. 
Figure 2 - Internal Conflict Variable, by country
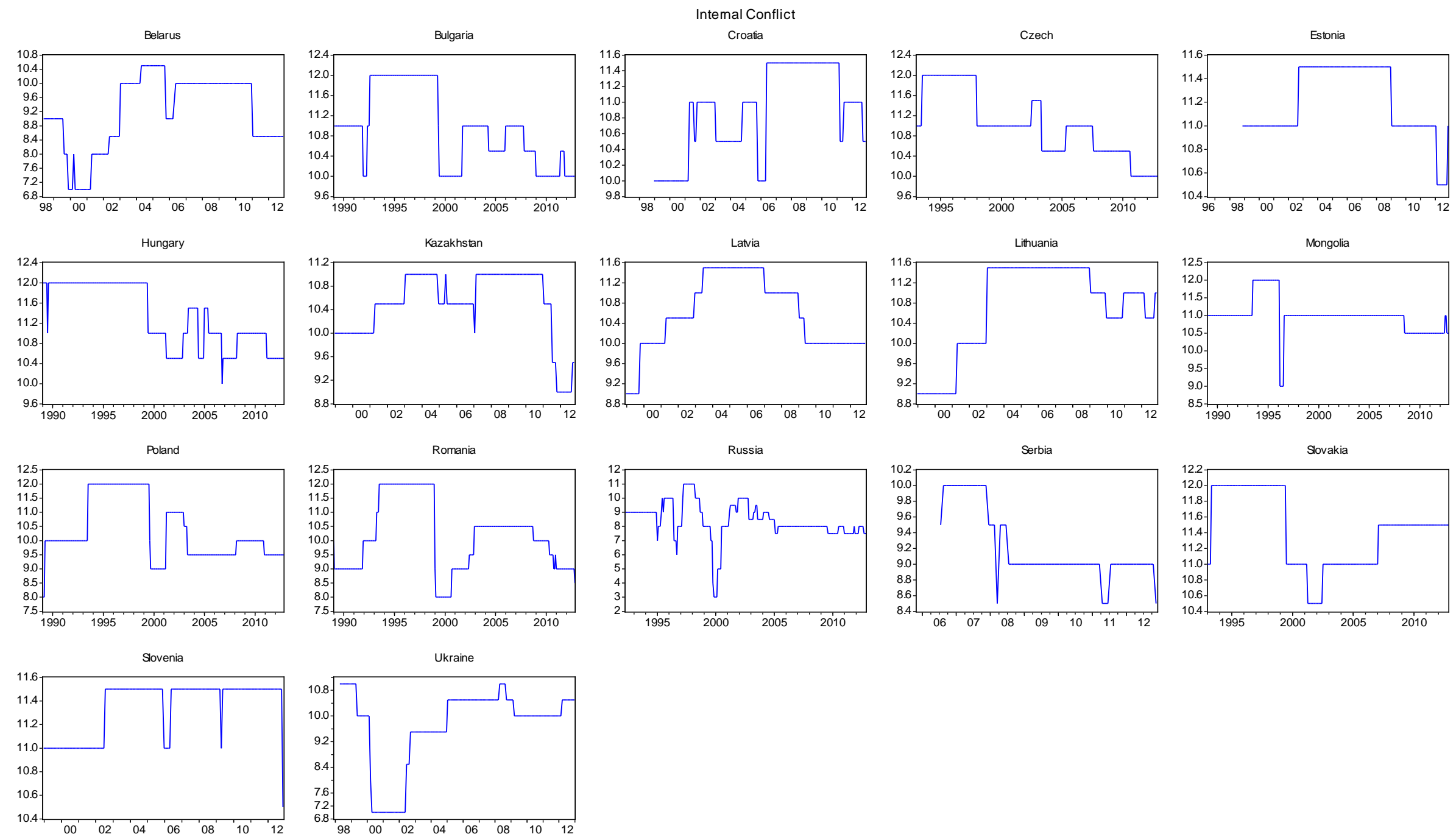
Table 1 - Summary Statistics

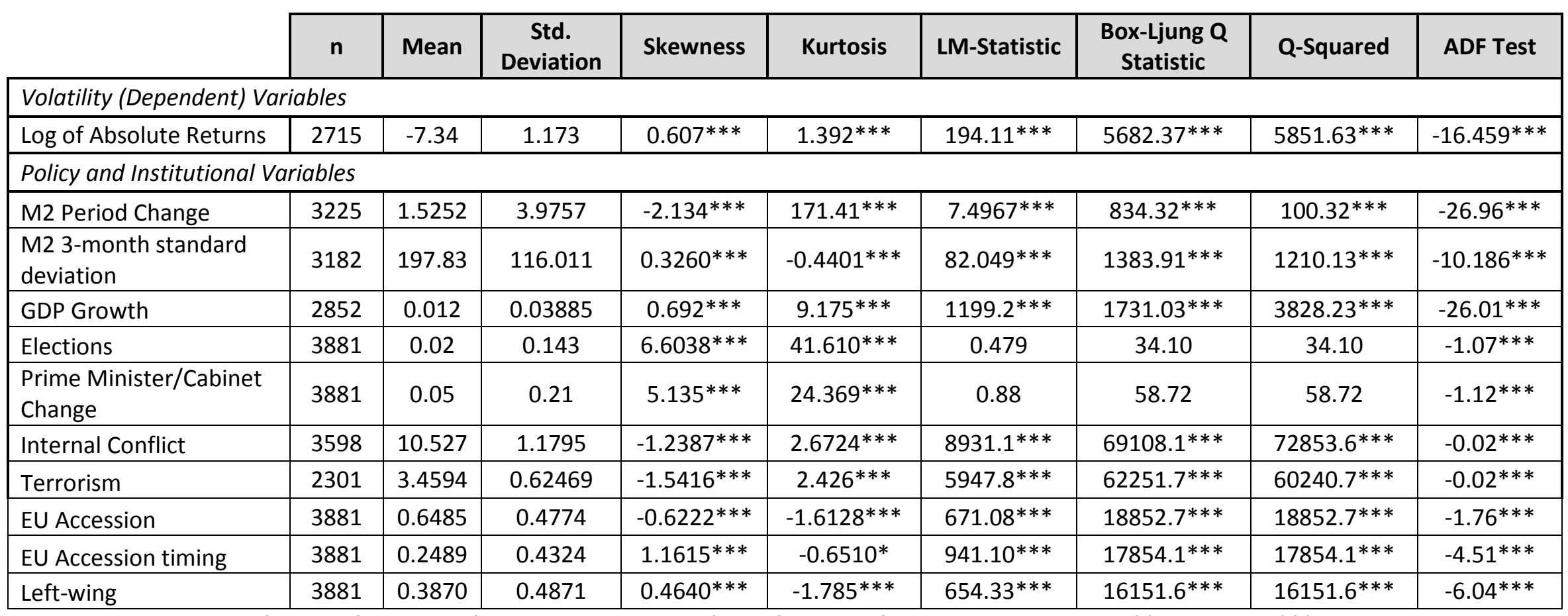

Note: significance of $p$-values of tests are shown, with * signifying significance at the $10 \%$ level, ${ }^{* *}$ at $5 \%$, and ${ }^{* * *}$ at $1 \%$. 
Table 2 - GARCH Regressions, Political Volatility v. Financial Volatility

\begin{tabular}{|c|c|c|c|c|}
\hline & 1 & 2 & 3 & 4 \\
\hline \multicolumn{5}{|l|}{ Conditional Mean Equation } \\
\hline \multicolumn{5}{|l|}{ FORMAL POLITICAL INSTABILITY } \\
\hline \multirow[t]{2}{*}{ Elections } & -0.07 & & -0.05 & \\
\hline & 1.18 & & 0.74 & \\
\hline \multirow[t]{2}{*}{ Prime Minister/Cabinet Changes } & & 0.04 & & 0.01 \\
\hline & & 1.01 & & 0.07 \\
\hline \multicolumn{5}{|l|}{ INFORMAL POLITICAL INSTABILITY } \\
\hline \multirow[t]{2}{*}{ Internal Conflict } & -0.06 & -0.06 & & \\
\hline & $7.44 * * *$ & $5.62 * * *$ & & \\
\hline \multirow[t]{2}{*}{ Terrorism } & & & -0.13 & -0.14 \\
\hline & & & $8.89 * * *$ & $7.85^{* * *}$ \\
\hline \multicolumn{5}{|l|}{ POLICY/INSTITUTIONAL VARIABLES } \\
\hline \multirow[t]{2}{*}{ M2 Change } & -0.0001 & -0.0001 & -0.0001 & -0.0001 \\
\hline & $3.15^{* * *}$ & $3.28^{* * *}$ & $2.98 * * *$ & $2.77 * * *$ \\
\hline \multirow[t]{2}{*}{ C } & -1.81 & -0.18 & -2.06 & -2.04 \\
\hline & $19.47^{* * *}$ & $15.60 * * *$ & $41.98 * * *$ & $28.91 * * *$ \\
\hline \multicolumn{5}{|l|}{ Conditional Variance Equation } \\
\hline \multirow[t]{2}{*}{ Elections } & 2.06 & & 2.41 & \\
\hline & $3.57^{* * *}$ & & $4.05^{* * *}$ & \\
\hline \multirow[t]{2}{*}{ Prime Minister/Cabinet Changes } & & 0.93 & & 0.59 \\
\hline & & 1.25 & & 0.61 \\
\hline \multirow[t]{2}{*}{ Internal Conflict } & 0.09 & 0.09 & & \\
\hline & $1.66^{*}$ & 1.61 & & \\
\hline \multirow[t]{2}{*}{ Terrorism } & & & 0.21 & 0.19 \\
\hline & & & $2.03^{* *}$ & $1.88^{*}$ \\
\hline \multirow[t]{2}{*}{ M2 Change } & 0.002 & 0.002 & 0.002 & 0.002 \\
\hline & $3.34 * * *$ & $2.92 * * *$ & $3.90 * * *$ & $2.27^{* *}$ \\
\hline $\mathrm{n}$ & 2434 & 2434 & 1889 & 1889 \\
\hline Log Likelihood & -1369.859 & -1398.73 & -1058.918 & -1073.84 \\
\hline AIC & 1.1634 & 1.1649 & 1.1413 & 1.1549 \\
\hline
\end{tabular}

Note: absolute values of $t$-stats are shown, with * signifying significance at the $10 \%$ level, ** at $5 \%$, and $* * *$ at $1 \%$. 
Table 3-GJR-GARCH Results, Full Control Set

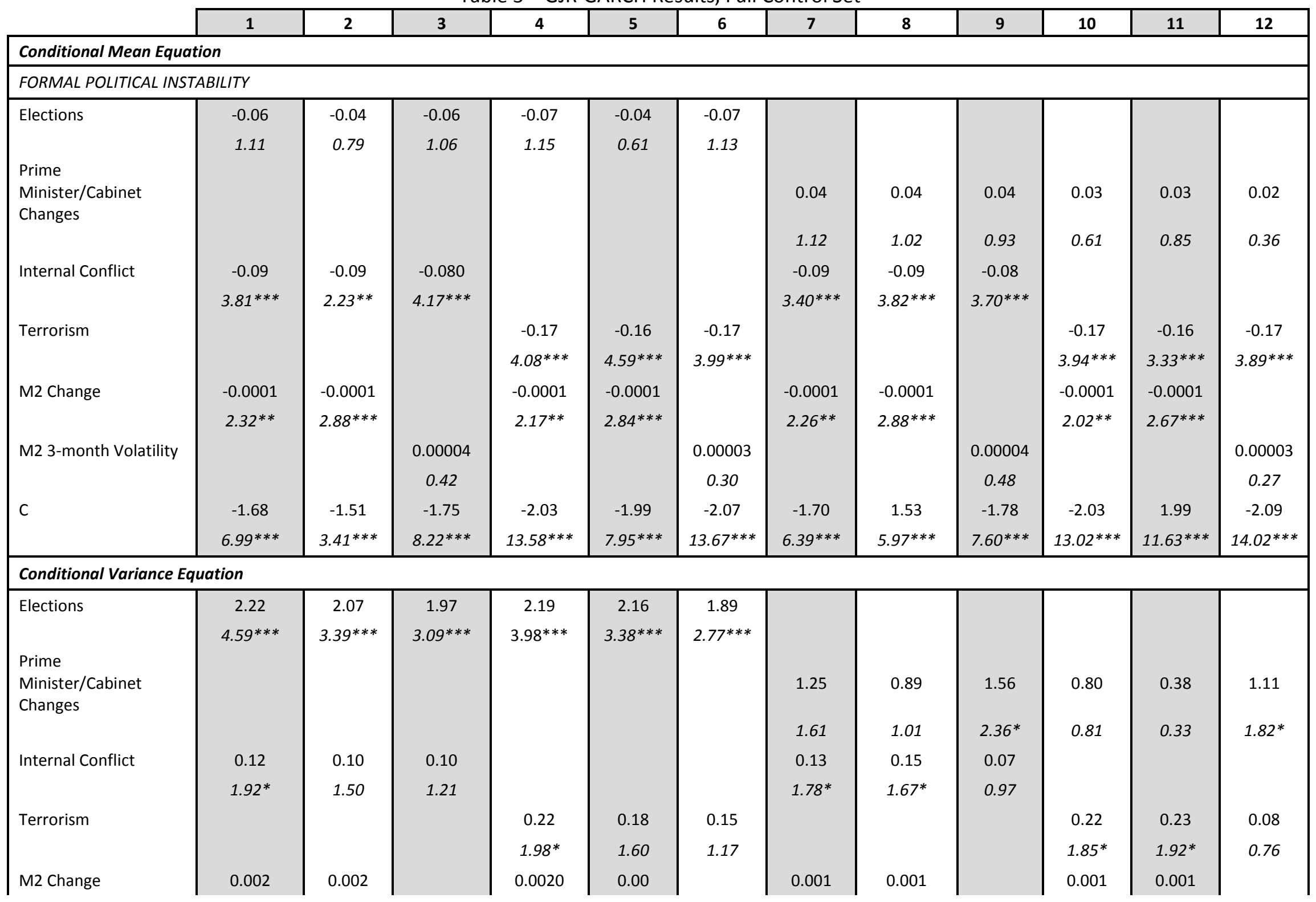




\begin{tabular}{|c|c|c|c|c|c|c|c|c|c|c|c|c|}
\hline & 1 & 2 & 3 & 4 & 5 & 6 & 7 & 8 & 9 & 10 & 11 & 12 \\
\hline M2 3-month Volatility & $2.23^{* *}$ & $\begin{array}{c}2.89^{* * *} \\
0.69\end{array}$ & $\begin{array}{c}0.003 \\
1.50\end{array}$ & $2.48^{* *}$ & $\begin{array}{c}2.90^{* * *} \\
0.36\end{array}$ & $\begin{array}{c}0.002 \\
1.46\end{array}$ & $1.81^{*}$ & $\begin{array}{l}0.97 \\
1.65^{*}\end{array}$ & $\begin{array}{l}0.004 \\
2.20^{*}\end{array}$ & $1.90^{*}$ & 1.21 & $\begin{array}{c}0.004 \\
2.88^{* * *}\end{array}$ \\
\hline $\mathrm{n}$ & 2187 & 2187 & 2181 & 1756 & 1756 & 1752 & 2187 & 2187 & 2181 & 1756 & 1756 & 1752 \\
\hline Log Likelihood & -1017.05 & -1184.25 & -1016.0 & -800.27 & -950.61 & -801.03 & -1019.21 & -1185.69 & -1016.40 & -803.43 & -952.68 & -805.81 \\
\hline AIC & 0.9511 & 1.1040 & 0.9528 & 0.9377 & 1.1089 & 0.9407 & 0.9531 & 1.1053 & 0.95 & 0.951 & 1.111 & 0.946 \\
\hline
\end{tabular}

Note: absolute values of $t$-stats are shown, with ${ }^{*}$ signifying significance at the $10 \%$ level, ${ }^{* *}$ at $5 \%$, and ${ }^{* * *}$ at $1 \%$. Full complement of controls included but removed for reasons of space (see Appendix). 
Table 4-Robustness Tests

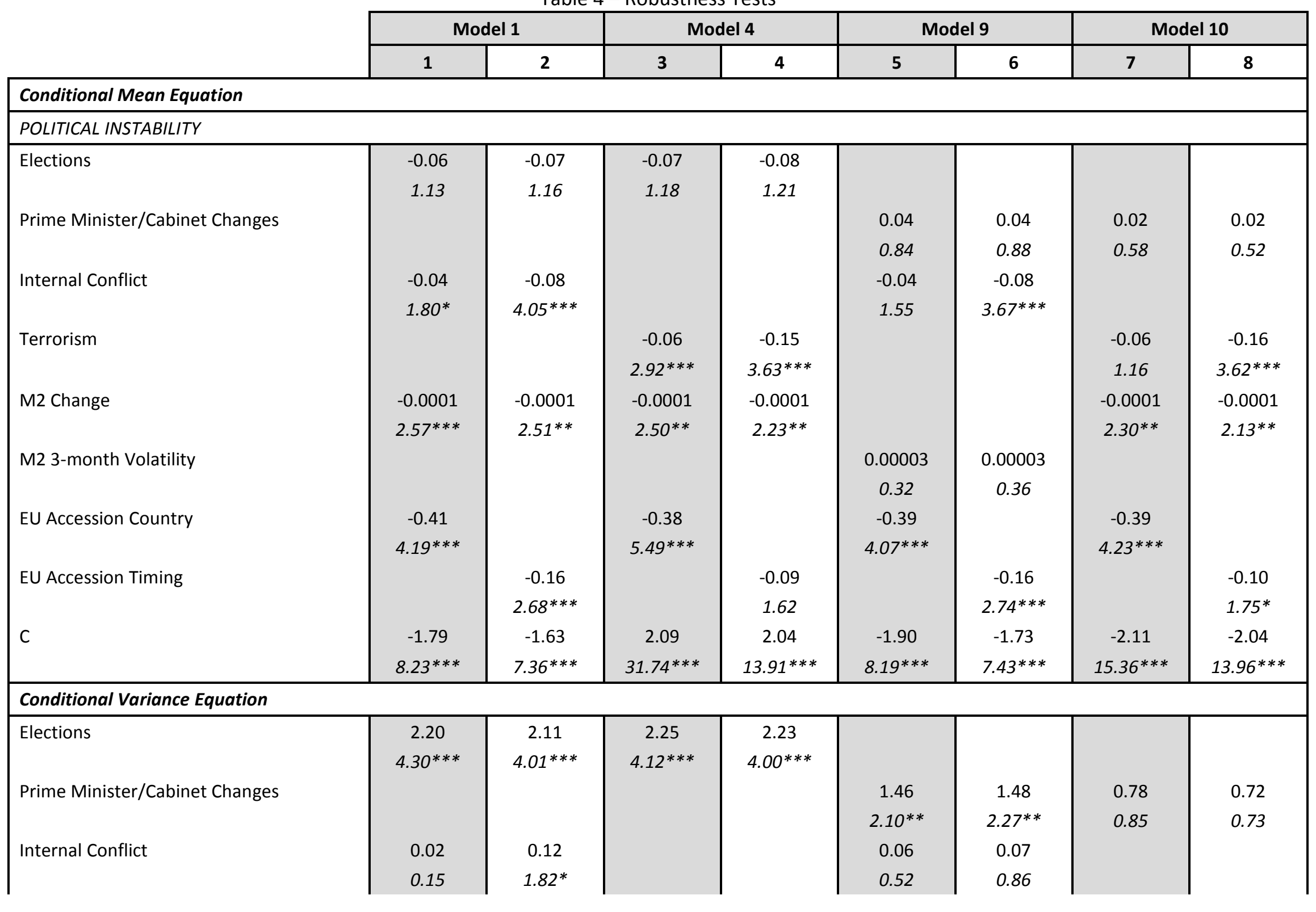




\begin{tabular}{|c|c|c|c|c|c|c|c|c|}
\hline & 1 & 2 & 3 & 4 & 5 & 6 & 7 & 8 \\
\hline \multirow[t]{2}{*}{ Terrorism } & & & 0.01 & 0.13 & & & 0.08 & 0.15 \\
\hline & & & 0.03 & 1.06 & & & 0.48 & 1.24 \\
\hline \multirow[t]{2}{*}{ M2 Change } & 0.002 & 0.002 & 0.002 & 0.002 & & & 0.002 & 0.002 \\
\hline & $2.67 * * *$ & $2.75 * * *$ & $2.87 * * *$ & $2.99 * * *$ & & & $2.09 * *$ & $2.36^{* *}$ \\
\hline \multirow[t]{2}{*}{ M2 3-month Volatility } & & & & & 0.004 & 0.004 & & \\
\hline & & & & & $1.70 *$ & $2.37^{*}$ & & \\
\hline \multirow[t]{2}{*}{ EU Accession Country } & 0.67 & & 0.67 & & 0.17 & & 0.44 & \\
\hline & 1.44 & & 1.58 & & 0.43 & & 1.01 & \\
\hline \multirow[t]{2}{*}{ EU Accession Timing } & & 0.31 & & 0.43 & & 0.22 & & 0.39 \\
\hline & & $1.77^{*}$ & & $1.77^{*}$ & & 1.19 & & 1.55 \\
\hline $\mathrm{n}$ & 2187 & 2187 & 1756 & 1756 & 2181 & 2181 & 1756 & 1756 \\
\hline Log Likelihood & -1004.38 & -1011.49 & -790.59 & -797.09 & -1005.90 & -1011.38 & -793.88 & -800.43 \\
\hline AIC & 0.9414 & 0.9479 & 0.9289 & 0.9363 & 0.95 & 0.95 & 0.93 & 0.94 \\
\hline
\end{tabular}

Note: absolute values of $t$-stats are shown, with * signifying significance at the $10 \%$ level, ** at $5 \%$, and *** at $1 \%$. Full complement of controls shown in Appendix. 
Table 5 - Regressions including Economic Policy Uncertainty

\begin{tabular}{|c|c|c|c|c|c|c|c|c|}
\hline & 1 & 2 & 3 & 4 & 5 & 6 & 7 & 8 \\
\hline \multicolumn{9}{|l|}{ Conditional Mean Equation } \\
\hline \multicolumn{9}{|l|}{ POLITICAL INSTABILITY } \\
\hline Elections & $\begin{array}{r}-0.06 \\
0.95\end{array}$ & $\begin{array}{r}-0.06 \\
1.02\end{array}$ & $\begin{array}{r}-0.08 \\
1.27\end{array}$ & $\begin{array}{r}-0.07 \\
1.08\end{array}$ & & & & \\
\hline \multirow[t]{2}{*}{ Prime Minister/Cabinet Changes } & & & & & 0.04 & 0.04 & 0.03 & 0.03 \\
\hline & & & & & 1.13 & 1.10 & 0.66 & 0.67 \\
\hline \multirow[t]{2}{*}{ Internal Conflict } & -0.09 & -0.09 & & & -0.09 & -0.08 & & \\
\hline & $4.06 * * *$ & $4.15^{* * *}$ & & & $4.12 * * *$ & $4.02 * * *$ & & \\
\hline \multirow[t]{2}{*}{ Terrorism } & & & -0.14 & -0.14 & & & -0.14 & -0.14 \\
\hline & & & $3.26 * * *$ & $3.34 * * *$ & & & $2.97 * * *$ & $3.10 * * *$ \\
\hline \multirow[t]{2}{*}{ M2 Change } & -0.0001 & -0.0001 & -0.0001 & -0.0001 & -0.0001 & -0.0001 & -0.0001 & -0.0001 \\
\hline & $2.53 * * *$ & $2.72 * * *$ & $2.39 * *$ & $2.63 * * *$ & $2.50 * *$ & $2.62 * * *$ & $2.26 * *$ & $2.36^{* *}$ \\
\hline \multirow[t]{2}{*}{ European Policy Uncertainty } & 0.0004 & & 0.0003 & & 0.0004 & & 0.0003 & \\
\hline & $1.71^{*}$ & & 1.43 & & $1.73^{*}$ & & 1.48 & \\
\hline \multirow[t]{2}{*}{ German Policy Uncertainty } & & 0.0001 & & 0.0001 & & 0.001 & & 0.001 \\
\hline & & 0.82 & & 0.80 & & 0.58 & & 0.97 \\
\hline \multirow[t]{2}{*}{$\mathrm{C}$} & -1.59 & -1.57 & -2.07 & -2.06 & -1.61 & -1.63 & -2.09 & -2.09 \\
\hline & $7.05^{* * *}$ & $6.94 * * *$ & $14.36^{* * *}$ & $14.13^{* * *}$ & $7.32 * * *$ & $7.36^{* * *}$ & $13.41 * * *$ & $14.03 * * *$ \\
\hline \multicolumn{9}{|l|}{ Conditional Variance Equation } \\
\hline \multirow[t]{2}{*}{ Elections } & 1.75 & 2.04 & 2.42 & 2.21 & & & & \\
\hline & $2.38 * *$ & $2.96 * * *$ & $3.68 * * *$ & $2.92 * * *$ & & & & \\
\hline \multirow[t]{2}{*}{ Prime Minister/Cabinet Changes } & & & & & 0.82 & 0.73 & 0.92 & 1.09 \\
\hline & & & & & 0.75 & 0.61 & 1.24 & 1.54 \\
\hline \multirow[t]{2}{*}{ Internal Conflict } & 0.11 & 0.10 & & & 0.20 & 0.11 & & \\
\hline & 1.44 & 1.38 & & & $2.20 * *$ & 1.41 & & \\
\hline \multirow[t]{2}{*}{ Terrorism } & & & 0.11 & 0.12 & & & 0.31 & 0.29 \\
\hline & & & 0.80 & 0.86 & & & $2.37^{* *}$ & $2.27^{* *}$ \\
\hline M2 Change & 0.002 & 0.002 & 0.002 & 0.002 & 0.001 & 0.002 & 0.001 & 0.001 \\
\hline
\end{tabular}




\begin{tabular}{|c|c|c|c|c|c|c|c|c|}
\hline $\begin{array}{l}\text { European Policy Uncertainty } \\
\text { German Policy Uncertainty }\end{array}$ & $\begin{array}{c}2.45^{* *} \\
0.02 \\
2.61 * * *\end{array}$ & $\begin{array}{c}0.004 \\
0.47\end{array}$ & $\begin{array}{c}3.02 * * * \\
-0.01 \\
0.89\end{array}$ & $\begin{array}{c}0.001 \\
0.33\end{array}$ & $\begin{array}{c}0.70 \\
0.02 \\
3.91^{* * *}\end{array}$ & $\begin{array}{l}0.01 \\
0.51\end{array}$ & $\begin{array}{c}1.09 \\
0.02 \\
3.28 * * *\end{array}$ & $\begin{array}{c}0.008 \\
2.33^{* * *}\end{array}$ \\
\hline$n$ & 2272 & 2272 & 1841 & 1841 & 2272 & 2272 & 1841 & 1841 \\
\hline Log Likelihood & -1094.89 & -1096.54 & -884.438 & -883.02 & -1095.26 & -1100.55 & -888.91 & -891.47 \\
\hline AIC & 0.9876 & 0.9890 & 0.9902 & 0.9886 & 0.99 & 0.99 & 1.00 & 1.00 \\
\hline Distribution & Student's T & Student's T & Student's T & Student's T & Student's T & GED & GED & GED \\
\hline
\end{tabular}

Note: absolute values of t-stats are shown, with * signifying significance at the $10 \%$ level, ** at the $5 \%$ level, and ${ }^{* * *}$ at the $1 \%$ level. Full complement of controls shown in Appendix. 